\title{
Network Effects, Consumer Expectations and Ride-hailing Rivalries: Understanding How Platform Entries Influence New Car Sales
}

\author{
Yue Guo \\ King's College London \\ yue.guo@kcl.ac.uk
}

\author{
Xiaotong Li \\ University of Alabama in Huntsville \\ lixi@uah.edu
}

\author{
Xiaohua Zeng \\ King's College London \\ xiaohua.zeng@kcl.ac.uk
}

\begin{abstract}
The gradual entries of ride-hailing platforms across China provide us with a unique opportunity to examine the interplay among network effects, consumer expectations and platform competition in the sharing economy. While recent empirical evidence shows that the initial entry of Didi Chuxing (the leading ride-hailing platform in China) positively impacts new car sales in the short run, our study demonstrates that, once the time window of investigation is expanded from one year to three years, the impacts of entries on new car sales turn negative. In addition, our analysis provides evidence suggesting that intensified competition resulting from platform rivalries can boost new car sales to alleviate the negative impacts in the short run.
\end{abstract}

\section{Introduction}

Economists have long been intrigued by network externalities and the resultant bandwagon effect commonly observed in markets where incompatible technologies/standards battle for dominance [27,48]. Network externalities (sometimes referred to as network effects) are associated with many Internetbased technologies. Consequently, many studies in the IS literature have focused on understanding their strategic implications for technology competition and IT adoption in the digital economy (e.g., [50,51,59]). Internet-enabled sharing platforms such as those of Uber and Airbnb operate in two-sided markets where there are both same-side and cross-side network effects. Given the prominent role played by those platforms in the sharing economy $[5,13,18,73,77]$, it is imperative to understand the implications of network effects for platform competition and market dynamics.

Using a dataset of new vehicle registrations from many Chinese cities, Guo et al. [36] investigate how the entries of Didi Chuxing (the dominant ride-hailing platform provider in $\mathrm{China}^{1}$ ) impact new car sales. Their empirical analysis shows that, within a one-year period, the entry of Didi Chuxing can meaningfully increase new car sales. This result is somewhat unexpected because conventional wisdom suggests that, as using ride-hailing apps becomes more affordable and convenient, most people will have weaker incentives to purchase a new car. Indeed, many Uber users have postponed their new car purchases because of the prevalence of ride-hailing services [24]. Moreover, facing increasingly intense competition from the ride-hailing platforms, many taxi companies have a strong disincentive to expand their fleets. Guo et al. [36] justify their empirical results by pointing out that, as many potential drivers in China need to acquire new cars to register for Didi Chuxing, the entries of this popular ride-hailing platform can quickly boost new car sales. Because of strong network externalities associated with this dominant platform and targeted auto dealer promotions (e.g., [60]), the overall impacts of Didi's entries on new car sales are likely to be positive in the short run.

Our study examines how Didi's entries impact new car sales within a three-year period. There are two reasons why expanding the investigative time window from one year to three years may yield new insights. First, the growing popularity of ride-hailing apps and the resultant publicity may influence consumer expectations well beyond the one-year time window. If consumers anticipate Didi Chuxing's entry in the near future, they will have weaker incentives to purchase new cars. Second, for those potential drivers who plan to register newly purchased cars for Didi or other platforms, they have a deferral option associated with their purchasing decisions. This option is valuable because of the significant uncertainty regarding the timing of the platform entry, platform registration requirements and the intensity of car dealer special promotions immediately following the entry. Thus, the

\footnotetext{
'Didi Chuxing acquired Uber's Chinese business in a deal worth US $\$ 35$ billion in 2016 [78]. According to cnbc.com and Wall Street Journal, Didi Chuxing's market valuation could reach US\$80 billion in a potential IPO in the second half of 2018.
} 
one-year time window cannot fully capture the potential impacts of this deferral option on new car sales. This deferral option is even more valuable when it is unclear which platform will emerge as the dominant ride-hailing service provider.

In our dataset, there are a few cities into which both Didi Chuxing and Uber China (the two major competing platforms at that time) entered. Because platform competition in two-sided markets are usually very intense $[64,68]$, it is plausible that the major rival's entry may considerably boost new car sales. Anecdotal evidence has shown that platform rivalries in two-sided markets often lead to below-cost pricing and prolonged platform subsidies [68]. Thus, we extend our empirical analysis to examine the overall impact of rival platform entries on new car sales within the three-year time window. Consequently, we can better understand the role played by platform competition in influencing market dynamics of the sharing economy.

The remainder of this paper is organized as follows. We review the related literature in Section 2. In Section 3, we describe the dataset and explain our research design. Section 4 summarizes and discusses the results of our statistical analyses. Section 5 concludes the paper.

\section{Prior Literature}

Recent studies have highlighted the increasingly intense competition faced by incumbent firms in several industries directly connected to the sharing economy [10, 20,30,37]. It has been demonstrated that popular online two-sided platforms can substitute and complement goods/services offered by the incumbent firms [22,61]. As a prominent example of two-sided platforms that are quickly gaining popularity in the sharing economy, ride-hailing apps have recently attracted the attention of many researchers (e.g., $[23,66,67,81])$. While the implications of the carsharing business for controlling pollution, improving traffic congestion, and reducing transportation costs have long been investigated [21, 29 44, 62], few studies have investigated the implications of ridehailing apps for new car demand.

Because there are quite a few antecedents and consequences related to decision-makers' participation in online two-sided platforms [4, 15, 34, 53, 78], the impacts of the emergence of two-sided platforms on the demand for the related goods/services are fairly complex [43, 46]. Guo et al. [36] contribute to this stream of research by empirically examining the impacts of Didi Chuxing's entries on new car sales in dozens of cities across China. Their analysis provides evidence of a positive impact of Didi's entries on new car sales. They point out that Didi Chuxing's dominant market position generates strong cross-side network effects that offer individuals strong incentives to buy new cars and register for Didi's platform. This is consistent with the insights from previous studies suggesting that, once a large network reaches critical mass, it can rapidly generate significant new demand because of positive network feedback [50,51,55,59].

Nevertheless, previous IS studies have highlighted the role individuals' expectations in influencing their decision-making (e.g., [8,51]). Because of the reputation of Didi Chuxing as the leading ride-hailing platform in China, its gradual entries into many Chinese cities can influence consumer expectations well beyond the one-year time window used in [36]. Moreover, as car-sharing has long been viewed by many people as a greener alternative to private car ownership, many potential car buyers' expectations may be affected by mechanisms like herding or informational cascades $([26,55])$.

A main insight from the real options literature is that the deferral option is very valuable when there is significant uncertainty about a new technology (e.g., $[51,57])$. Facing significant uncertainty surrounding the ride-hailing business model, many potential car buyers may retain their deferral options to let uncertainty be resolved over time, which also suggests that the investigative time window for Didi's entries needs to be expanded. In addition, extant literature on two-sided platforms has suggested that platform competition is usually very intense and prolonged platform subsidies are fairly common $[64,68]$. Under these scenarios, competing platforms may make greater efforts to expand the network of their registered drivers. As their efforts often incentivize potential car buyers to purchase new cars, intense platform competition may considerably boost new car sales in the short run.

\section{Research Design}

To investigate the competition effect of two leading ride-hailing apps (i.e., Didi Chuxing and Uber) on new car sales, we created a national monthly panel dataset from Jan 2013 to Dec 2015 for 50 prefecture-level cities. These cities include 32 cities where only Didi Chuxing entered during the observation period and 18 cities where both Didi Chuxing and Uber entered. Thus, this dataset allows us to investigate both the effect of Didi Chuxing's entry and the coexistence (or competition) effect of Didi Chuxing and Uber. Our analysis follows two steps. Firstly, we considered the above 50 cities as a treated group and we created an 
untreated group (i.e., cities where no ride-hailing apps entered) using the propensity score matching (PSM) method. Secondly, a difference-in-difference analysis was performed on the two groups to infer the impacts of entries and the competition effect on new car sales.

In this study, we identified another 50 prefecturelevel cities as the untreated (i.e., control) group. We performed the PSM method so that the untreated cities have similar probability (or propensity score) of becoming the treated cities but they did not. By ensuring the comparability of the treated group and untreated group, the PSM method helps reduce the endogeneity concern [41].

To calculate the propensity score, we included the factors that reflect the demographic, social and economic status of a city because these factors might influence the entry decision of ride-hailing apps. Specifically, we included per capita income, GDP growth rate and population size because they reflect the level of urbanization of each city. We also included the number of mobile phone subscriptions, the geographic coverage of public transportation (i.e., the total number of registered public buses), and the intensity of paved roads, each of which can influence the use of ride-hailing apps. These variables are largely downloaded from the China City Statistical Yearbook, which is an annual official statistical report that summarizes key indicators of the economic and social development of China. All key variables are available both at the national level and at the local level (province, autonomous region, and municipality under the direct control of Central Government). Based on the propensity scores of the cities, we employ the nearest neighbor matching algorithm with replacement and caliper (0.05). The intuition behind matching is that the more similar the treated and untreated cities are in the above observed characteristics, the less likely they are to differ in unobserved ways.

Table 1. Summary of descriptive statistics

\begin{tabular}{|c|c|c|c|c|}
\hline Variable & Mean & $\begin{array}{l}\text { Std. } \\
\text { Dev }\end{array}$ & Min & Max \\
\hline DiDi Entry & 0.099 & $\begin{array}{l}0.29 \\
9\end{array}$ & $\begin{array}{l}0.00 \\
0\end{array}$ & 1.000 \\
\hline Uber Entry & 0.461 & $\begin{array}{l}0.21 \\
0\end{array}$ & $\begin{array}{l}0.00 \\
0\end{array}$ & 1.000 \\
\hline $\begin{array}{l}\text { Ln } \\
\text { (Newcarsale) }\end{array}$ & 8.393 & $\begin{array}{l}0.86 \\
7\end{array}$ & $\begin{array}{l}6.01 \\
6 \\
\end{array}$ & 10.998 \\
\hline $\begin{array}{l}\text { Ln } \\
\text { (Population) }\end{array}$ & 6.217 & $\begin{array}{l}0.68 \\
3\end{array}$ & $\begin{array}{l}3.40 \\
0\end{array}$ & 8.124 \\
\hline In(Employed) & 4.310 & $\begin{array}{l}0.75 \\
7\end{array}$ & $\begin{array}{l}2.28 \\
7\end{array}$ & 6.589 \\
\hline $\begin{array}{l}\text { Ln } \\
\text { (Registered } \\
\text { Unemployed) }\end{array}$ & 1.013 & $\begin{array}{l}0.91 \\
9\end{array}$ & $\begin{array}{l}- \\
2.38 \\
8\end{array}$ & 4.095 \\
\hline
\end{tabular}

\begin{tabular}{|c|c|c|c|c|}
\hline $\begin{array}{l}\text { Ln (Average } \\
\text { Wage) }\end{array}$ & 10.917 & $\begin{array}{l}0.20 \\
1\end{array}$ & $\begin{array}{l}10.2 \\
57\end{array}$ & 11.636 \\
\hline $\begin{array}{l}\text { Ln (GRP Per } \\
\text { Capita) }\end{array}$ & 11.072 & $\begin{array}{l}0.53 \\
6\end{array}$ & $\begin{array}{l}9.21 \\
9\end{array}$ & 12.579 \\
\hline $\begin{array}{l}\text { Ln (Mobile } \\
\text { Subscribers) }\end{array}$ & 6.416 & $\begin{array}{l}0.68 \\
3\end{array}$ & $\begin{array}{l}4.02 \\
5\end{array}$ & 8.313 \\
\hline $\begin{array}{l}\text { Ln (Internet } \\
\text { Subscribers) }\end{array}$ & 4.663 & $\begin{array}{l}0.74 \\
2\end{array}$ & $\begin{array}{l}2.48 \\
5\end{array}$ & 7.094 \\
\hline $\begin{array}{l}\text { Ln (Highway } \\
\text { Passenger } \\
\text { Traffic) }\end{array}$ & 8.956 & $\begin{array}{l}1.05 \\
9\end{array}$ & $\begin{array}{l}4.64 \\
4\end{array}$ & 12.016 \\
\hline Ln (Buses) & 7.444 & $\begin{array}{l}1.02 \\
9\end{array}$ & $\begin{array}{l}5.42 \\
1\end{array}$ & 10.072 \\
\hline $\begin{array}{l}\text { Ln (Bus } \\
\text { Passenger } \\
\text { Volume) }\end{array}$ & 9.997 & $\begin{array}{l}1.24 \\
1\end{array}$ & $\begin{array}{l}5.43 \\
8\end{array}$ & 13.090 \\
\hline Ln (Taxis) & 8.059 & $\begin{array}{l}1.11 \\
6\end{array}$ & $\begin{array}{l}5.56 \\
1\end{array}$ & 11.131 \\
\hline $\begin{array}{l}\text { Ln (Road } \\
\text { Area Per } \\
\text { Capita) }\end{array}$ & 2.627 & $\begin{array}{l}0.53 \\
8\end{array}$ & $\begin{array}{l}1.01 \\
2\end{array}$ & 4.686 \\
\hline $\begin{array}{l}\text { Ln (Metro } \\
\text { Length) }\end{array}$ & 0.830 & $\begin{array}{l}1.78 \\
3\end{array}$ & $\begin{array}{l}0.00 \\
0\end{array}$ & 6.443 \\
\hline \multicolumn{5}{|c|}{$\begin{array}{l}\text { Note: The units of population, employed and registered } \\
\text { unemployed population, mobile subscribers, internet } \\
\text { subscribers, number of buses, bus passenger volume, } \\
\text { highway passenger traffic are } 10,000 \text {. }\end{array}$} \\
\hline \multicolumn{5}{|c|}{$\begin{array}{l}\text { The unit of the number of Taxi is one car. The units of } \\
\text { average Wage and GRP Per Capita are RMB. }\end{array}$} \\
\hline
\end{tabular}

\section{Methodology and Results}

\subsection{Difference-in-difference model}

We first examine the impacts of Didi Chuxing's entry on new car sales in cities where there was no competition from Uber. Our analysis focuses on the 32 cities where only Didi Chuxing entered during the observation period and those cities in the control group. We employ the following difference-indifference specification:

$$
\operatorname{Ln}\left(Y_{c t}\right)=\boldsymbol{A}_{c}+\boldsymbol{B}_{t}+g \cdot \boldsymbol{Z}_{c t}+p \cdot \boldsymbol{R}_{c t}+e_{c t},
$$

where $\mathrm{c}$ represents cities and $\mathrm{t}$ refers to month (from January 2013 to December 2015); Y $c t$ is the number of new car registration plates for city $\mathrm{c}$ at time t; Ac represents a vector capturing city fixed effects; and $\mathbf{B t}$ represents a vector capturing time fixed effects. Furthermore, $\mathbf{Z}_{\mathrm{ct}}$ represents a vector reflecting city demographical features and socioeconomic indicators, such as population size, GDP growth rate, per capita income, the number of mobile phones possessed, per capita bus transportation, and per capita road kilometers. Descriptive statistics of these variables are listed in Table 1. Moreover, Rct is a binary variable that indicates the entry of the ride-hailing app. In this 
case, $\mathbf{R}_{\mathrm{ct}}=1$ if Didi Chuxing was available in city $\mathrm{c}$ at time $\mathrm{t}$, otherwise $\mathbf{R}_{\mathrm{ct}}=0$. $e_{c t}$ represents an error term. The coefficient $p$ is the DID estimator which represents the impact of Didi Chuxing's entry on new car sales. Table 2 reports the estimates. The results show that Didi Chuxing's entry has a significant negative impact on new car sales (beta $=-0.348$ ).

We extend our analysis to examine the impact of the competition between Uber and Didi Chuxing on new car sales. Our analysis includes all the 50 treated cities and the 50 untreated cities. We modified equation (1) as follows:

$$
\begin{aligned}
& \operatorname{Ln}\left(Y_{c t}\right)=\boldsymbol{A}_{c}+\boldsymbol{B}_{t}+g \cdot \boldsymbol{Z}_{c t}+m \cdot \boldsymbol{D}_{c t}+n \cdot \boldsymbol{U}_{c t}+ \\
& p \cdot \boldsymbol{D} \boldsymbol{U}_{c t}+e_{c t}
\end{aligned}
$$

where DUct is a binary variable to indicate the entry of both Didi and Uber. In this case, DUct $=1$ if Didi Chuxing and Uber are both available in city $\mathrm{c}$ at time $\mathrm{t}$, otherwise DUct $=0$. Table 3 reports the estimates. We can see a significant decrease (betas $=-0.340$ and 0.200 ) in new car sale after the entry of either Didi Chuxing or Uber. Interestingly, the additional effect due to competition was positive (beta=0.084) when both Didi and Uber entered the same cities. Because the magnitude of this competition effect is smaller than that of the entry by a single ride-hailing app, the result implies that competition can alleviate the effect of sales reduction. One explanation is that, because of the fierce competition, the two ride-hailing service platforms might have significantly increased cash subsidies to motivate drivers to purchase new cars and register the new cars for their platforms.

Table 2. Difference-in-difference model: the impact of Didi on new car sale

\begin{tabular}{|l|l|}
\hline Dependent Variable & Ln (NumCars) \\
\hline Didi Entry & $\begin{array}{l}-0.348^{\star \star \star} \\
(0.026)\end{array}$ \\
\hline In(Population) & $\begin{array}{l}-0.069 \\
(0.270)\end{array}$ \\
\hline In(Employed) & $\begin{array}{l}0.328^{\star \star \star} \\
(0.078)\end{array}$ \\
\hline Ln (Registered Unemployed) & $\begin{array}{l}-0.027 \\
(0.022)\end{array}$ \\
\hline Ln (Average Wage) & $\begin{array}{l}0.833^{\star \star *} \\
(0.110)\end{array}$ \\
\hline Ln (GRP Per Capita) & $\begin{array}{l}-0.124^{\star *} \\
(0.054)\end{array}$ \\
\hline Ln (Mobile Subscribers) & $\begin{array}{l}0.153^{\star \star} \\
(0.075)\end{array}$ \\
\hline Ln (Internet Subscribers) & $\begin{array}{l}0.089^{\star} \\
(0.053)\end{array}$ \\
\hline Ln (Highway Passenger Traffic) & $\begin{array}{l}-0.005 \\
(0.020)\end{array}$ \\
\hline
\end{tabular}

\begin{tabular}{|l|l|}
\hline Ln (Buses) & $\begin{array}{l}0.074^{*} \\
(0.019)\end{array}$ \\
\hline Ln (Bus Passenger Volume) & $\begin{array}{l}0.025 \\
(0.020)\end{array}$ \\
\hline Ln (Taxis) & $\begin{array}{l}-0.005 \\
(0.030)\end{array}$ \\
\hline Ln (Road Area Per Capita) & $-0.104^{* *}$ \\
& $(0.044)$ \\
\hline \hline Ln (Metro Length) & 0.029 \\
& $(0.018)$ \\
\hline Observations & 2952 \\
\hline R-squared & 0.890 \\
\hline Month FE & Yes \\
\hline City FE & Yes \\
\hline Note: Robust standard errors clustered at city level \\
in parentheses. ${ }^{* * *} p<0.01,{ }^{* *} p<0.05,{ }^{*} p<0.1$
\end{tabular}

Table 3. Difference-in-difference model: the

\begin{tabular}{|c|c|}
\hline Dependent Variable & Ln(NumCars) \\
\hline Didi Entry & $\begin{array}{l}-0.340^{* * *} \\
(0.025)\end{array}$ \\
\hline Uber Entry & $\begin{array}{l}-0.200^{* \star \star} \\
(0.044)\end{array}$ \\
\hline Didi Entry and Uber entry & $\begin{array}{l}0.084^{*} \\
(0.051)\end{array}$ \\
\hline In(Population) & $\begin{array}{l}-0.455 \\
(0.263)\end{array}$ \\
\hline In(Employed) & $\begin{array}{l}0.310^{* \star *} \\
(0.074)\end{array}$ \\
\hline Ln (Registered Unemployed) & $\begin{array}{l}-0.026 \\
(0.021)\end{array}$ \\
\hline Ln (Average Wage) & $\begin{array}{l}0.857^{\star \star *} \\
(0.107) \\
\end{array}$ \\
\hline Ln (GRP Per Capita) & $\begin{array}{l}-0.041 \\
(0.042) \\
\end{array}$ \\
\hline Ln (Mobile Subscribers) & $\begin{array}{l}0.160^{\star *} \\
(0.072)\end{array}$ \\
\hline Ln (Internet Subscribers) & $\begin{array}{l}-0.054 \\
(0.036)\end{array}$ \\
\hline $\begin{array}{l}\text { Ln (Highway Passenger } \\
\text { Traffic) }\end{array}$ & $\begin{array}{l}-0.039^{\star \star} \\
(0.016)\end{array}$ \\
\hline Ln (Buses) & $\begin{array}{l}0.090^{\star \star *} \\
(0.019)\end{array}$ \\
\hline Ln (Bus Passenger Volume) & $\begin{array}{l}0.048^{* *} \\
(0.020)\end{array}$ \\
\hline Ln (Taxis) & $\begin{array}{l}-0.021 \\
(0.030)\end{array}$ \\
\hline Ln (Road Area Per Capita) & $\begin{array}{l}-0.084^{*} \\
(0.043)\end{array}$ \\
\hline Ln (Metro Length) & $\begin{array}{l}0.020^{*} \\
(0.012)\end{array}$ \\
\hline Observations & 3600 \\
\hline R-squared & 0.890 \\
\hline Month FE & Yes \\
\hline City FE & Yes \\
\hline \multicolumn{2}{|c|}{$\begin{array}{l}\text { Note: Robust standard errors clustered at city leve } \\
\text { in parentheses. }{ }^{* \star}{ }^{* *} p<0.01,{ }^{* *} p<0.05,{ }^{*} p<0.1\end{array}$} \\
\hline
\end{tabular}
competition effect of Didi and Uber 


\subsection{Relative time model}

Our previous analyses show the impacts on new cars sales after the ride-hailing apps entered the cities. However, because the news about a ride-hailing platform's entry is usually announced to the public a few months in advance, consumers might have reacted before the actual entry month. Therefore, we examine the lead-lag effect of ride-hailing apps on new car sales using a relative time model as suggested by [9]. Relative time models have been widely used in the extant literature (e.g., $[19,39])$. We add time dummy variables $\left(\boldsymbol{R}_{c t}^{j}\right)$ for up to five months before Didi's entry, and four months after Didi's entry, where $\mathrm{j}$ belongs to $\{-5,-4 \ldots, 3,4$ and forward $\}$, indicating whether month $t$ is the jth month since Didi Chuxing becomes available in a city. Further, we multiply the entry dummies with a weight (w) which measures the unemployed population/10,000 in a city. The idea is that the entry of ride-hailing apps may create different "competition intensity" across the cities. As the entry creates new job opportunities, it may produce stronger impacts in cities with significant unemployed population. The relative time model is shown as below:

$\operatorname{Ln}\left(Y_{c t}\right)=\boldsymbol{A}_{c}+\boldsymbol{B}_{t}+g \cdot \boldsymbol{Z}_{c t}+\sum_{j} w p_{j} \cdot \boldsymbol{R}_{c t}^{j}+e_{c t}$

Table 4 reports the coefficient estimations. The results show that, as we expected, Didi's entries can negatively impact new car sales for a few months prior to the official Didi entry month. More specifically, we can see a significantly negative impact on new car sales for up to five months prior to Didi's entry.

Similarly, we can examine the lead-lag effects under the scenario where Didi and Uber entered the same city. A modified version of Equation (3) is used for the relative time analysis:

$$
\begin{aligned}
& \operatorname{Ln}\left(Y_{c t}\right)=\boldsymbol{A}_{c}+\boldsymbol{B}_{t}+g \cdot \boldsymbol{Z}_{c t}+m \cdot \boldsymbol{D}_{c t}+n \cdot \boldsymbol{U}_{c t}+ \\
& \sum_{j} w p_{j} \cdot \boldsymbol{D} \boldsymbol{U}_{\boldsymbol{c t}}^{j}+e_{c t},
\end{aligned}
$$

where $\mathrm{j}$ belongs to $\{-2,-1,0,1,2,3\}$, representing whether month $t$ is the jth month since Didi Chuxing and Uber both become available in a city. We estimated fewer lead months here because usually the rival platform followed the incumbent platform very soon (usually in three months). The results are reported in Table 5. There was a significant increase $(1.3 \%)$ in the number of car registrations immediately after Didi and Uber both entered the same city. The effect lasts for a relatively short period (i.e., two months) and then gradually diminishes.

\begin{tabular}{|c|c|}
\hline Dependent Variable & Ln(NumCars) \\
\hline Didi Entry_prior5_w & $\begin{array}{l}-0.087^{* * *} \\
(0.0112)\end{array}$ \\
\hline Didi Entry_prior4_w & $\begin{array}{l}-0.093^{\star \star \star} \\
(0.012)\end{array}$ \\
\hline Didi Entry_prior3_w & $\begin{array}{l}-0.076^{* * *} \\
(0.112) \\
\end{array}$ \\
\hline Didi Entry_prior2_w & $\begin{array}{l}-0.072^{\star \star \star} \\
(0.112)\end{array}$ \\
\hline Didi Entry_prior1_w & $\begin{array}{l}-0.076^{* * *} \\
(0.012)\end{array}$ \\
\hline Didi Entry_month_w & $\begin{array}{l}-0.069^{* * *} \\
(0.012)\end{array}$ \\
\hline Didi Entry_after1_w & $\begin{array}{l}-0.063^{\star \star \star} \\
(0.012)\end{array}$ \\
\hline Didi Entry_after2_w & $\begin{array}{l}-0.070^{\star * \star} \\
(0.012)\end{array}$ \\
\hline Didi Entry_after3_w & $\begin{array}{l}-0.078^{* * *} \\
(0.012)\end{array}$ \\
\hline Didi Entry_after4forward_w & $\begin{array}{l}-0.088^{\star \star \star} \\
(0.012)\end{array}$ \\
\hline In(Population) & $\begin{array}{l}-0.357 \\
(0.257)\end{array}$ \\
\hline In(Employed) & $\begin{array}{l}0.202^{\star \star *} \\
(0.075)\end{array}$ \\
\hline Ln (Registered Unemployed) & $\begin{array}{l}-0.014 \\
(0.021)\end{array}$ \\
\hline Ln (Average Wage) & $\begin{array}{l}0.613^{\star \star \star \star} \\
(0.106)\end{array}$ \\
\hline Ln (GRP Per Capita) & $\begin{array}{l}-0.111^{* *} \\
(0.052)\end{array}$ \\
\hline Ln (Mobile Subscribers) & $\begin{array}{l}0.491^{* * *} \\
(0.075) \\
\end{array}$ \\
\hline Ln (Internet Subscribers) & $\begin{array}{l}0.092^{*} \\
(0.050)\end{array}$ \\
\hline $\begin{array}{l}\text { Ln (Highway Passenger } \\
\text { Traffic) }\end{array}$ & $\begin{array}{l}-0.0002^{* *} \\
(0.019)\end{array}$ \\
\hline Ln (Buses) & $\begin{array}{l}0.056^{\star \star *} \\
(0.019) \\
\end{array}$ \\
\hline Ln (Bus Passenger Volume) & $\begin{array}{l}0.010^{* *} \\
(0.019)\end{array}$ \\
\hline Ln (Taxis) & $\begin{array}{l}-0.018 \\
(0.028)\end{array}$ \\
\hline Ln (Road Area Per Capita) & $\begin{array}{l}-0.112^{* * *} \\
(0.042)\end{array}$ \\
\hline Ln (Metro Length) & $\begin{array}{l}0.025^{*} \\
(0.018)\end{array}$ \\
\hline Observations & 2952 \\
\hline R-squared & 0.900 \\
\hline Month FE & Yes \\
\hline City FE & Yes \\
\hline \multicolumn{2}{|c|}{$\begin{array}{l}\text { Note: Robust standard errors clustered at city } \\
\text { level in parentheses. }{ }^{* * \star} p<0.01,{ }^{* \star} p<0.05,{ }^{*} \\
p<0.1 \text {. }\end{array}$} \\
\hline
\end{tabular}

Table 4. Relative time model: Didi entry only 
Table 5. Relative time model: Didi and Uber both entry

\begin{tabular}{|c|c|}
\hline Dependent Variable & Ln(NumCars) \\
\hline Didi Entry & $\begin{array}{l}-0.341^{\star \star \star} \\
(0.024)\end{array}$ \\
\hline Uber Entry & $\begin{array}{l}-0.172^{* * *} \\
(0.036)\end{array}$ \\
\hline Both Entry_prior2_w & $\begin{array}{l}-0.007 \\
(0.005)\end{array}$ \\
\hline Both Entry_prior1_w & $\begin{array}{l}-0.006 \\
(0.005) \\
\end{array}$ \\
\hline Both Entry_month_w & $\begin{array}{l}0.013^{\star *} \\
(0.006)\end{array}$ \\
\hline Both Entry_after1_w & $\begin{array}{l}0.009^{*} \\
(0.006)\end{array}$ \\
\hline Both Entry_after2_w & $\begin{array}{l}0.007 \\
(0.006)\end{array}$ \\
\hline Both Entry_after3_w & $\begin{array}{l}0.002 \\
(0.006)\end{array}$ \\
\hline $\begin{array}{l}\text { Both } \\
\text { Entry_after4forward_w }\end{array}$ & $\begin{array}{l}0.0004 \\
(0.003)\end{array}$ \\
\hline $\ln ($ Population) & $\begin{array}{l}-0.434^{*} \\
(0.263)\end{array}$ \\
\hline In(Employed) & $\begin{array}{l}0.301^{\star \star \star} \\
(0.074)\end{array}$ \\
\hline $\begin{array}{l}\text { Ln (Registered } \\
\text { Unemployed) }\end{array}$ & $\begin{array}{l}-0.027 \\
(0.021) \\
\end{array}$ \\
\hline Ln (Average Wage) & $\begin{array}{l}0.848^{\star \star \star \star} \\
(0.108)\end{array}$ \\
\hline Ln (GRP Per Capita) & $\begin{array}{l}-0.042 \\
(0.043) \\
\end{array}$ \\
\hline $\begin{array}{l}\text { Ln (Mobile } \\
\text { Subscribers) }\end{array}$ & $\begin{array}{l}0.161^{* *} \\
(0.072)\end{array}$ \\
\hline $\begin{array}{l}\text { Ln (Internet } \\
\text { Subscribers) }\end{array}$ & $\begin{array}{l}-0.054 \\
(0.036) \\
\end{array}$ \\
\hline $\begin{array}{l}\text { Ln (Highway } \\
\text { Passenger Traffic) }\end{array}$ & $\begin{array}{l}-0.039^{* *} \\
(0.016)\end{array}$ \\
\hline Ln (Buses) & $\begin{array}{l}0.089^{\star \star *} \\
(0.019) \\
\end{array}$ \\
\hline $\begin{array}{l}\text { Ln (Bus Passenger } \\
\text { Volume) }\end{array}$ & $\begin{array}{l}0.047^{\star \star} \\
(0.020)\end{array}$ \\
\hline Ln (Taxis) & $\begin{array}{l}-0.020 \\
(0.030)\end{array}$ \\
\hline $\begin{array}{l}\text { Ln (Road Area Per } \\
\text { Capita) }\end{array}$ & $\begin{array}{l}-0.081^{*} \\
(0.043) \\
\end{array}$ \\
\hline Ln (Metro Length) & $\begin{array}{l}0.023^{*} \\
(0.012)\end{array}$ \\
\hline Observations & 3600 \\
\hline R-squared & 0.900 \\
\hline Month FE & Yes \\
\hline City FE & Yes \\
\hline \multicolumn{2}{|c|}{$\begin{array}{l}\text { Note: Robust standard errors clustered at city } \\
\text { level in parentheses. }{ }^{* * *} p<0.01,{ }^{* *} p<0.05,{ }^{*} \\
p<0.1 \text {. We don't report the estimation of control } \\
\text { variables because of the page limit }\end{array}$} \\
\hline
\end{tabular}

\section{Discussions and Conclusion}

The gradual entries of ride-hailing platforms across China provide us with a unique opportunity to examine the interplay among network effects, consumer expectations and platform competition in the sharing economy. Our study provides empirical evidence showing that the initial entry of Didi Chuxing (the leading ride-hailing platform in China) negatively impacts new car sales. This negative impact occurs as early as five months prior to the official entry month. We point out that this early impact is likely caused by consumer expectations and those people who retain their valuable real options by deferring their car purchasing decisions. More interestingly, our analysis suggests that intensified competition resulting from the entries of two major competing platforms can alleviate the negative impact on new car sales in the short run. In other words, while car sharing may reduce the purchase of new cars and promote more sustainable travel behavior, platform rivalries in the market can boost new car demand and consequently alleviate the new car sales decline driven by platform entries.

Our study contributes to the growing literature that focuses on the interactions between traditional industries and digital start-ups in the sharing economy (e.g., [20,36,37]). It is worth noting that strong network externalities have both positive impacts and negative impacts on new car sales. They positively impact new car sales by offering new drivers strong incentives to join major ride-hailing platforms, and they negatively impact new car sales by making it increasingly convenient for people to use ride-hailing apps, thereby making private car ownerships less appealing. Therefore, to fully assess the impacts of platform entries on new car sales, we also need to pay attention to consumer expectations and platform competition. Our results suggest that, on the one hand, consumers' expectations about future platform entries and their real option thinking can negatively influence new car sales several months before the official entry month. On the other hand, because of the fierce competition driven by cross-side network effects, platform competition can significantly boost new car sales to alleviate the negative impact, at least in the short run. These observations are consistent with the insights from previous studies demonstrating expectations, learning, competition and uncertainty play important roles in markets subject to strong network externalities (e.g., [26,50,51,55,56,59]).

Our study also contributes to the extant literature on two-sided platform competition (e.g., [64,68]). Our empirical results suggest that competing platforms have made efforts to quickly expand the networks of their registered drivers by incentivizing new car 
purchases in the short run. While the impacts of these platform rivalries on new car sales may be transitory, the social welfare implications of platform competition are less clear, and they consequently merit future investigations. Furthermore, the increasingly fierce rivalry between Didi Chuxing and Meituan (the dominant Chinese group-buying platform) highlights the importance of understanding extrinsic network effects in platform competition. Extrinsic network effects are indirect network externalities created by complementary products or services $[12,33,59]$. By leveraging its massive group buying network, Meituan has quickly emerged as a major threat to Didi Chuxing's dominance in the ride-hailing business. We believe that future empirical studies may shed fresh light on the role played by indirect network externalities in influencing competitive dynamics of the sharing economy.

\section{References}

[1]. Agatz, N. A., Erera, A. L., Savelsbergh, M. W., \& Wang, X (2011). Dynamic ride-sharing: A simulation study in Metro Atlanta. Transportation Research Part B: Methodological, 45(9), 1450-1464.

[2]. Allison, P.D., \& Waterman, R.P (2002). Fixed-effects negative binomial regression models. Sociological Methodology, 32(1), 247-265.

[3]. Armstrong, M. (2006). Competition in two-sided markets. The RAND Journal of Economics, 37(3), 68691.

[4]. Abramova, O., Shavanova, T., Fuhrer, A., Krasnova, H., \& Buxmann, P. (2015). Understanding the sharing economy: The role of response to negative reviews in the peer-to-peer accommodation sharing network. Twenty-Third European Conference on Information Systems (ECIS), Münster, Germany, 2015.

[5]. Adner R and Kapoor R. (2010). Value creation in innovation ecosystems: How the structure of technological interdependence affects firm performance in new technology generations. Strategic Management Journal, 31(3), 306-333

[6]. Athey, S. and Stern, S. (2002). The impact of information technology on emergency health care outcomes. RAND Journal of Economics, 33(3), 399-432.

[7]. Alexander L and Gonz'alez MC (2015). Assessing the impact of real-time ridesharing on urban traffic using mobile phone data. Proc. UrbComp 1-9, 2015

[8]. Au, Y. and Kauffman R. (2003). What Do You Know? Rational Expectations in Information Technology Adoption and Investment. Journal of Management Information Systems, 20(2), 49-76.

[9]. Autor, D.H. 2003. Outsourcing at Will: The Contribution of Unjust Dismissal Doctrine to the Growth of Employment Outsourcing. Journal of Labor Economics. 21(1) 1-42.
[10]. Barro, J. (2014). Under pressure from Uber, taxi medallion prices are plummeting. The New York Times. Available at: http://www.nytimes.com, 2014

[11].Bailey, J. P and Bakos, J. Y.(1997). An exploratory study of the emerging role of electronic intermediariations and policy, International Journal of Electronic Commerce, 1(3), 7-20.

[12]. Basu A, Mazumdar T, Rai S (2003). Indirect network externality effects on product attributes. Marketing Science, 22(2):209-222

[13]. Brynjolfsson, E., Hu, Y., and Smith, M. D. (2003). Consumer surplus in the digital economy: Estimating the value of increased product variety at online booksellers. Management Science, 49(11), 1580-1596.

[14].Bertrand, M., Duflo, E.,and Mullainathan, S.(2004). How much should we trust differences-in-differences estimates? Quarterly Journal of Economics, 119(1), 249-275.

[15].Burtch, G., Ghose, A., and Wattal, S. (2013). An empirical examination of the antecedents and consequences of contribution patterns in crowd-funded markets. Information Systems Research, 24(3), 499-519.

[16]. Carpenter, C. (2005). Youth alcohol use and risky sexual behavior: Evidence from underage drunk driving laws. Journal of Health Economics, 24(3), 613-628.

[17]. Chasin, F. and Scholta, H (2015). Taking peer-to-peer sharing and collaborative consumption onto the next level - new opportunities and challenges for egovernment. Twenty-Third European Conference on Information Systems (ECIS), Münster, Germany, (2015).

[18].Constantinides P and Barrett M. (2014). Information infrastructure development and governance as collective action. Information Systems Research 26(1), 40-56.

[19]. Chan J and Ghose A (2014). Internets dirty secret: assessing the impact of online intermediaries on HIV transmission. MIS Quarterly 38(4), 955-976

[20]. Cramer, J. and Krueger, A.B. (2016). Disruptive change in the taxi business: The case of Uber. The American Economic Review, 106(5), 177-182.

[21]. Cervero, R., Golub, A., and Nee, B. (2007). City car share: Longer-term travel demand and car ownership impacts. Transportation Research Record, 1992, 70-80.

[22]. Cusumano M.A.(2015). How traditional firms must compete in the sharing economy. Communications of the ACM, 58(1), 32-34

[23]. Cohen, M. and Sundararajan, A. (2015). Self-regulation and innovation in the peer-to-peer sharing economy. University of Chicago Law Review Dialogue, 82, 116.

[24]. DeAmicis, C. (2015). Uber Users Are Waiting to Buy Cars Because of Uber. Recode. Available at: http://www.recode.net/2015/10/6/11619250/uber-usersare-waiting-to-buy-cars-because-of-uber

[25]. Dranove, D., Kessler, D., McClellan, M., and Satterthwaite, M. (2003). Is more information better? The effects of "report cards" on health care providers. Journal of Political Economy, 111(3), 555-588.

[26]. Duan W, Gu B, Whinston A. (2009). Informational cascades and software adoption on the Internet: an empirical investigation, MIS Quarterly, 33(1), 23-48. 
[27].Economides, N. (1996). The economics of networks. International Journal Industrial Organization, 16(4), 673-699.

[28].eMarketer. (2016). How much more can ride-sharing services grow in the US? Available at: https://www.emarketer.com/Article/How-Much-MoreRide-Sharing-Services-Grow-US/1013963

[29]. Fellows, N. T., and Pitfield, D.E. (2000). An economic and operational evaluation of urban car-sharing. Transportation Research D, 5(1), 1-10.

[30]. Fischer-Baum, R., and Bialik, C. (2015). Uber is taking millions of Manhattan rides away from taxis: The rideshare service probably isn't increasing congestion. FiveThirtyEight Economics. Available at: http://fivethirtyeight.com/features.2015

[31]. Fiegerman, S. (2014). Uber CEO: We're creating 50,000 new jobs per month, Mashable. Available at: http://mashable.com. 2014

[32]. Galbreth, M.R., Ghosh, B., and Shor, M. (2012). Social sharing of information goods: implications for pricing and profits. Marketing Science, 31(4), 603-620.

[33]. Gallaugher J, Wang Y (2002) Understanding network effects in software markets: evidence from web server pricing, MIS Quarterly, 26(4):303-327.

[34].Gerber, E. M., and Hui, J. (2013). Crowdfunding: Motivations and deterrents for participation. ACM Transactions on Computer-Human Interaction (TOCHI), 20(6), 34.

[35].Gopal, R. D., Bhattacharjee, S. and Sanders, G.L. (2005). Do artists benefit from online music sharing? Journal of Business, 79 (May), 1503-1533.

[36].Guo Y., F. Xin, S. Barnes and X. Li. (2018). Opportunities or Threats: The Rise of Online Collaborative Consumption (OCC) and its Impact on New Car Sales, Electronic Commerce Research and Applications, 29, 133-141.

[37]. Guttentag, D. (2015). Airbnb: Disruptive innovation and the rise of an informal tourism accommodation sector. Current issues in Tourism, 18(12), 1192-1217.

[38]. Greenwood and Agarwal R. (2015). Matching platforms and HIV incidence: An empirical investigation of race, gender, and socioeconomic status. Management Science, 62(8), 2281-2303

[39]. Greenwood, BN andWattal S. (2015). Show me the way to go home: an empirical investigation of ride sharing and alcohol related motor vehicle homicide. Fox School of Business Research Paper (15-054)

[40]. Hall, J., Kendrick, C., and Nosko, C. (2015). The effects of uber's surge pricing: A case study. Working Paper, Booth School of Business, The University of Chicago

[41].Hennig-Thurau, T., Henning, V., and Sattler, H. (2007). Consumer file sharing of motion pictures. Journal of Marketing, 71(4), 1-18.

[42].Heckman, J and Navarro-Lozano, S. (2004). Using Matching, Instrumental Variables and Control Functions to Estimate Economic Choice Models. Review of Economics and Statistics, 86(1), 30-57.

[43].Horton, J. J., and Zeckhauser, R. J. (2016). Owning, using and renting: some simple economics of the sharing economy, Working Paper. Available at: http://www.nber.org/papers/w22029
[44]. Jacobson, S. H., \& King, D.M. (2009). Fuel saving and ridesharing in the US: Motivations, limitations, and opportunities. Transportation Research Part D, 14, 1421

[45]. Jin, G. Z., and Rysman, M. (2015). Platform Pricing at Sports Card Conventions. The Journal of Industrial Economics, 63(4), 704-735.

[46].Jiang, B., and Tian, L. (2016). Collaborative consumption: strategic and economic implications of product sharing, Management Science, 2016

[47]. Kaiser, U. and Wright, J. (2006). Price Structure in twosided markets: Evidence from the magazine industry. International Journal of Industrial Organization, 24(1), 1-28.

[48]. Katz M. and Shapiro, C. (1994) System competition and network effects. Journal of Economic Perspectives, 8(2), 93-115.

[49]. Kauffman, R. J., Lai, H. and Ho, C. (2010). Incentive mechanisms, fairness and participation in online groupbuying auctions. Electronic Commerce Research and Applications, 9(3), 249-262.

[50]. Kauffman R. J. and Li, X. (2003). Payoff externalities, informational cascades and managerial incentives: a theoretical framework for IT adoption herding, Proceedings of the 2003 INFORMS Conference on IS and Technology, Atlanta, GA

[51]. Kauffman R. J. and Li, X. (2005). Technology Competition and Optimal Investment Timing-A Real Options Model, IEEE Transactions on Engineering Management, 52(1), 15-29.

[52]. Knight, S. (2016). How Uber conquered London, The Guardian. Available at: https://www.theguardian.com

[53]. Kim J, Yoon Y, Zo. H. (2015). Why people participate in the sharing economy: A social exchange perspective. PACIS 2015 Proceedings

[54].Landsman V. and Stremersch. S. (2011). Multihoming in two-sided markets: An empirical inquiry in the video game console industry. Journal of Marketing 75(6), 39$54,2011$.

[55].Li, X. (2004). Informational Cascades in IT Adoption. Communications of the ACM, 47(4), 93-97.

[56].Li, X. (2005). Cheap Talk and Bogus Network Externalities in the Emerging Technology Market, Marketing Science, 24(4), 531-543.

[57].Li, X. (2009). Preemptive learning, competency traps and information technology adoption: a real options analysis. IEEE Transactions on Engineering Management, 56(4), 650-662.

[58].Li, X. (2014). Relational Contracts, Growth Options and Heterogeneous Beliefs: A Game-Theoretic Perspective on IT Outsourcing. Journal of Management Information Systems, 31(2), 319-350.

[59].Li, X., Kauffman, R. J., Yu, F. and Zhang, Y. (2014). Externalities, incentives and strategic complementarities: understanding herd behavior in IT adoption. Information Systems and e-Business Management, 12(3), 443-464.

[60].Lutz, H. (2015). Toyota financial to provide leasing options for Uber drivers, Automotive News. Available at: http://www.autonews.com. 2015 
[61]. Malhotra A, Van Alstyne M. (2014). The dark side of the sharing economy...and how to lighten it. Communications of the ACM, 57(11), 24-27.

[62]. Martin, E., Shaheen, S., and Lidicker, J. (2010). Impact of Carsharing on household vehicle holdings: Results from north American shared-use vehicle survey. Transportation Research Record: Journal of the Transportation Research Board, 2143, 150-158.

[63]. Michel, N. J. (2006). The impact of digital file sharing on the music industry: An empirical analysis. Topics in Economic Analysis \& Policy, 6(1), 1-22

[64].Parker, G. and Alstyne, M. (2005). Two-Sided Network Effects: A Theory of Information Product Design. Management Science, 51(10), 1491-1504.

[65].Peitz, M., and Waelbroeck, P. (2004). The effect of internet piracy on music sales: Cross-section evidence. Review of Economic Research on Copyright Issues, 1(2), 71-79.

[66]. Rauch, D.E. and Schleicher, D. (2015). Like Uber, but for local government law: The future of local regulation of the sharing economy. George Mason Law \& Economics Research Paper No.15-01. Available at: http://dx.doi.org/10.2139/ssrn.2549919.

[67]. Ranchordás, S. (2015). Does sharing mean caring: Regulating innovation in the sharing economy. Minnesota Journal of Law, Science \& Technology. 16, 413.

[68]. Rochet, J. and J. Tirole (2003). Platform Competition in Two-Sided Markets. Journal of the European Economic Association, 1(4): 990-1029.

[69]. Rosoff, M. (2015). Uber is now more valuable than Ford, GM, and a bunch of huge public companies. Business Insider. Available at: http://uk.businessinsider.com.

[70]. Rogers, E. (2003). Diffusion of Innovations, 5th Edition. Simon and Schuster

[71].Smith, M.D. and Telang, R. (2009). Competing with free: The impact of movie broadcasts on DVD sales and Internet piracy. MIS Quarterly 33(2), 321-338.
[72]. Seamans R and Zhu, F. (2013). Responses to entry in multi-sided markets: The impact of craigslist on local newspapers. Management Science 60(2), 476-493.

[73]. Tilson D, Lyytinen K, Sørensen, C. (2010). Research commentary: digital infrastructures: the missing is research agenda. Information Systems Research 21(4), $748-759$.

[74]. Uber (2016). Where is Uber currently available? Available at: https://www.uber.com/cities.

[75]. Ungemah, D., Goodin, G., Dusza, C., and Burris, M. (2007) Examining incentives and preferential treatment of carpools on managed lane facilities. Journal of Public Transportation, 10(4), 151-169.

[76]. Weinberger, M. (2016) Uber to merge with Chinese rival Didi in $\$ 35$ billion deal. Business Insider. Available at: http://uk.businessinsider.com

[77]. Weber, T. A. (2014). Intermediation in a sharing economy: Insurance, moral hazard, and rent extraction. Journal of Management Information Systems, 31(3), 3571.

[78]. Weber, T. A. (2016). Product Pricing in a peer-to-peer economy. Journal of Management Information Systems, 32(2). 573-596.

[79]. Van Den Heever, C. (2016). Uber China faces a massive challenge in the China market. CKGSB Knowledge. Available at: http://knowledge.ckgsb.edu.cn. 2016

[80].Zentner, A. (2006). Measuring the effect of file sharing on music purchases, Journal of Law and Economics, 49 (April), 63-90.

[81].Zha, L., Yin, Y., and Yang, H. (2016). Economic analysis of ride-sourcing markets. Transportation Research Part C: Emerging Technologies, 71. 249-266.

[82].Zervas, G., Proserpio, D. and Byers, J.W. (2017). The rise of the sharing economy: Estimating the impact of Airbnb on the hotel industry, Journal of Marketing Research, 54, 5, 687-705. 